\title{
Corrosion Potential Assessment of Reinforcement Mechanical Properties Embedded in Concrete in Accelerated Corrosive Medium
}

\section{Charles Kennedy ${ }^{1}$, Nzidee Lelesi Futurehope, Charles Esther Nwochigziri}

${ }^{1}$ Faculty of Engineering, Department of Civil Engineering, Rivers State University, Nkpolu, Port Harcourt, Nigeria.

${ }^{2,}$ School of Engineering, Department of Mechanical Engineering, Kenule Beeson Saro-Wiwa Polytechnic, Bori, Rivers State, Nigeria

${ }^{3}$ Department of Chemistry, Ignatius Ajuru University of Education Rumuolimini, Port Harcourt, Rivers State, Nigeria Authors E-mail: ${ }^{1}$ ken_charl@yahoo.co.uk, ${ }^{2}$ geonatt16@gmail.com, ${ }^{3}$ wato4eva@yahoo.com

\section{Abstract}

Corrosion of reinforcing steel causes damage to concrete structures and it is a very costly problem in terms of its financial implications and also for its structures safety. This experimental work evaluated comparatively the effect of uncoated and exudates / resin coated reinforcement with celtis zenkeri of varying thickness $150 \mu \mathrm{m}, 300 \mu \mathrm{m}$ and $450 \mu \mathrm{m}$, inserted into concrete slab and accelerated in corrosive madia for 150 days to monitored and ascertained corrosion potential rates and mechanical properties effect of reinforcing steel using half cell potential, concrete resistivity measurement, tensile strength tests. Average potential $\mathrm{E}_{\text {corr }}$ percentile corroded specimen value is $337.1527 \%$ and percentile difference $237.1527 \%$ against $-70.3398 \%$ and $-67.7193 \%$ of control and coated specimens. Averaged percentile results of concrete resistivity $\rho, \mathrm{k} \Omega \mathrm{cm}$ value is $45.81129 \%$ and percentile difference $-54.1887 \%$ against $118.2868 \%$ and $117.675 \%$ of control and coated specimens. Average mechanical properties "ultimate strength" of percentile average value of corroded specimen is $108.7799 \%$ and percentile difference $8.779928 \%$ against $-8.07128 \%$ and $7.93467 \%$ of control and coated specimens. Results showed high ultimate yielding of corroded specimens to control and coated specimens due to the effect of corrosion on the mechanical properties of the steel reinforcement. Average mechanical properties "weight loss of steel" of corroded specimen percentile difference $82.23808 \%$ against $-45.1267 \%$ and $45.4432 \%$ of control and coated specimens. Results of weight loss of steel showed higher percentile values against control and coated specimens due to the effect of corrosion on the mechanical properties of steel. Average mechanical properties "cross- section area reduction" percentile average value $86.17593 \%$ and percentile difference $-13.8241 \%$ against $16.04169 \%$ and $16.04169 \%$. Cross- section area reduction results showed higher percentile reduction values due to effect of corrosion on the mechanical properties of steel.

Key Words: Corrosion, Corrosion inhibitors, corrosion potential, concrete resistivity and Steel Reinforcement.

\subsection{INTRODUCTION}

Cracks can reduce the overall strength and stiffness of the concrete structure and accelerate the ingress of aggressive ions, leading to other types of concrete deterioration and resulting in further cracking ${ }^{[1]}$. Cracked concrete surrounding corroded reinforcements and stirrups 
influences the anchorage and shear capacity of a beam. If the concrete in this region has been cracked by corrosion, it has reached its maximum tensile strength. Cracked concrete not only affects actual shear and anchorage capacities but also reduces the load-carrying capacity of a structure over the longer term by giving less protection to reinforcement and by allowing an aggressive environment direct access to the reinforcement. Corrosion of reinforcing steel causes damage to concrete structures and it is a very costly problem in terms of its financial implications and also for its structures safety $\left({ }^{[2],}{ }^{[3]}\right)$. It is therefore, necessary to develop methods which can increase the surface life of these structures. One method of corrosion prevention is proper concrete design. Corrosion inhibitors are widely used to delay corrosion of reinforcing steel in concrete, it acts by forming an impervious film on the metal surface or by interfering with either the anodic or cathodic reactions, or both of them. Some inhibitors such as chromates and benzoates have been shown ( ${ }^{[4],[5]}$ ) to reduce the corrosion rate of steel bar, however, but they also reduce the compressive strength of concrete but inorganic inhibitors are seen to be friendly to the environment and less cost effective.

${ }^{[6]}$ proposed that for the active state the B value in the Stern-Geary equation be $26 \mathrm{mV}$, and for the passive state $52 \mathrm{mV}$. Using equation (2.21), the value $\mathrm{B}=26 \mathrm{mV}$ can be obtained if both Tafel slopes are equal to $120 \mathrm{mV} /$ decade; and for $\mathrm{B}=52 \mathrm{mV}$ one of the Tafel slopes could be infinity and the other $120 \mathrm{mV} / \mathrm{dec}$ ade.

[7] Suggested that $B$ value for steel in concrete might range from as low as $8 \mathrm{mV}$ to approaching infinity under different conditions.

${ }^{[8]}$ Investigated the electrochemical processed that led to the electron transfer in corrosion process of steel reinforcement in the harsh marine environment with high level of chloride.. Average results on comparison showed incremental values of $70.1 \%$ against $27.2 \%$ Control of potential and $87.8 \%$ to $38.8 \%$ decremented values in concrete resistivity, yield stress against ultimate strength at summary and average state of corroded slab with nominal values of $100 \%$ and decremented in ultimate strength from $100.68 \%$ to $96.12 \%$, weight loss versus cross-section diameter reduction decremented due to assail from sodium chloride from $67.1 \%$ to $48.5 \%$ and $98.2 \%$ to $94.82 \%$ respectively. Average percentile results of potential and concrete resistivity are $29.9 \%$ and $63.6 \%$ respectively. When compared to corroded samples, corroded has $70.1 \%$ incremented values potential Ecorr, $\mathrm{mV}$ and $38.8 \%$ decremented values of concrete resistivity, yield stress against ultimate vigor at in comparison to corrode as $100 \%$ nominal yield stress decremented from $103.06 \%$ to $96.12 \%$ and weight loss at $67.5 \%$ against $48.5 \%$ and $47.80 \%$ to $94.82 \%$ cross-sectional diameter reduction, both showed decremented values of corroded compared to coated specimens.

[9] Investigated the corrosion potential, concrete resistivity and tensile tests of Control, corroded and coated reinforcing steel of concrete slab member. Average results on comparison showed an increase of $70.1 \%$ against $27.2 \%$ Control of Potential Ecorr, $\mathrm{mV}$ and $87.8 \%$ to $38.8 \%$, decreased values in concrete resistivity. Yield stress against ultimate strength at summary and average state of corroded slab with nominal values of $100 \%$ and decreased in ultimate strength from $100.68 \%$ to $96.12 \%$, weight loss versus cross-section diameter reduction decreased due to attack from sodium chloride from $67.1 \%$ to $48.5 \%$ and $98.2 \%$ to $94.82 \%$ respectively. When compared to corroded samples, corroded has $70.1 \%$ increased values potential and $38.8 \%$ decreased values of concrete resistivity, yield stress against ultimate strength at in comparison to corrode as $100 \%$ nominal yield stress decreased from $100.95 \%$ to $96.12 \%$ and figures 3.5 and 3.6 respectively presented weight loss at $67.5 \%$ against $48.5 \%$ and $98.7 \%$ to $94.82 \%$, cross-sectional diameter reduction, both showed decreased values of corroded compared to coated specimens. The entire results showed effectiveness in the use of dacroyodes edulis as inhitors, it sustained and preserved the reinforcement against environmental. 
${ }^{110]}$ Investigated the effects of chloride attack on reinforcing steel embedded in reinforced concrete structures built in the marine environment. Average percentile results of potential Ecorr, $\mathrm{mV}$, and concrete resistivity are $27.45 \%$ and $68.45 \%$ respectively. When compared to corroded samples, corroded has $75.4 \%$ increased values potential Ecorr,mV and $33.54 \%$ decreased values of concrete resistivity, yield stress against ultimate strength at in comparison to corrode as $100 \%$ nominal yield stress decremented from $108.38 \%$ to $90.25 \%$ respectively, weight loss at $69.3 \%$ against $43.98 \%$ and $51.45 \%$ to $89.25 \%$, cross-sectional diameter reduction, both showed decreased values of corroded compared to coated specimens.

${ }^{[11]}$ Investigated corrosion level probability assessment potential through half cell potential corrosion measurement, concrete resistivity test and tensile strength test mechanical properties of control, corroded and inhibited reinforcement with moringa oleifera lam resin paste of trees extract. Average percentile results of potential Ecorr,mV, and concrete resistivity are $29.9 \%$ and $68.74 \%$ respectively. When compared to corroded samples, corroded has $70.1 \%$ increased values potential Ecorr,mV and $35.5 \%$ decreased values of concrete resistivity. Results of computed percentile average values of yield stress against ultimate strength, when compared to corrode as $100 \%$ nominal yield stress decremented from $105.75 \%$ to $96.12 \%$ and weight loss at $67.5 \%$ against $48.5 \%$ and $48.34 \%$ to $94.82 \%$, crosssectional diameter reduction, both showed decreased values of corroded compared to coated specimens.

[12] investigated the use of inorganic inhibitors and Greener approach inhibitors to evaluate the assessment of corrosion potential using Mangifera indica resins paste extracts.. Average percentile results of potential Ecorr,mV, and concrete resistivity are $26.57 \%$ and $61.25 \%$ respectively. When compared to corroded samples, corroded has $70.1 \%$ increased values potential Ecorr, $\mathrm{mV}$ and $38.8 \%$ decreased values of concrete resistivity, yield stress against ultimate strength at summary and average state of corroded slab with nominal values of $100 \%$ and decremented in ultimate strength from $105.36 \%$ to $96.12 \%$, weight loss versus crosssection diameter reduction decreased due to attack from sodium chloride from $64.8 \%$ to $44.45 \%$ and $46.76 \%$ to $86.43 \%$ respectively.

${ }^{[13]}$ Investigated corrosion probability level assessments of three different resins extracts of trees from dacryodes edulis, mangifera indica and moringa oleifera lam using half cell potential corrosion measurement, concrete resistivity measurement and tensile strength test to ascertain the surface condition of the mechanical properties of control, corroded and inhibited reinforcement. When compared to corroded samples, corroded has $70.1 \%$ increased values potential Ecorr, $\mathrm{mV}$ and $35.5 \%$ decreased values of concrete resistivity. Average percentile results of potential Ecorr, $\mathrm{mV}$, and concrete resistivity are dacryodes edulis $29.9 \%$ and $63.6 \%$, mangifera indica $26.57 \%$ and $61.25 \%$ and moringa oeifera lam $29.9 \%$ and $68.74 \%$ respectively. Arbitrarily and computed percentile average values of yield stress against ultimate strength, when compared to corrode as $100 \%$ nominal yield stress decreased from $100.95 \%$ to $96.12 \%$ dacryodes edulis inhibited, $105.36 \%$ to $96.12 \%$ mangifera indica inhibited, and $105.75 \%$ to $96.12 \%$ moringa oleifera lam inhibited and weight loss of dacryodes edulis inhibited are $67.5 \%$ against $48.5 \%$ and $98.7 \%$ to $94.82 \%$, cross-sectional diameter reduction, mangifera indica inhibited specimen $64.8 \%$ to $44.45 \%$ and $46.76 \%$ to $86.43 \%$ cross-sectional diameter reduction and moringa oleifera lam inhibited specimen $67.5 \%$ against $48.5 \%$ and $48.34 \%$ to $94.82 \%$, cross-sectional diameter reduction, all showed decreased values of corroded compared to coated specimens.

${ }^{[14]}$ Examined the effectiveness in the utilization of three eco-friendly inorganic inhibitors tree extract exudates / resins of Symphonia globulifera linn, Ficus glumosa and Acardium occidentale 1 . When compared to corroded samples, corroded has $70.1 \%$ incremented values potential Ecorr,mV and $38.8 \%$ decremented values of concrete resistivity. $69.3 \%$ against 
$43.98 \%$ and $51.45 \%$ to $89.25 \%$, cross-sectional diameter reductions, both showed decremented values of corroded compared to coated specimens. General and compute percentile average values of yield stress against ultimate strength at in comparison to corrode as $100 \%$ nominal yield stress decremented ultimate strength from $103.06 \%$ to $96.12 \%$, $112.48 \%$ to $89.25 \%$, and $108.38 \%$ to $90.25 \%$ of Symphonia globulifera linn, Ficus glumosa and Acardium occidentale 1 respectively, weight loss at of corroded against inhibited Symphonia globulifera linn specimens at $67.5 \%$ against $48.5 \%$ and $47.80 \%$ to $94.82 \%$, inhibited Ficus glumosa $69.5 \%$ to $47.29 \%$, $48.95 \%$ to $77.89 \%$ and inhibited acardium occidentale 1. Average percentile results of potential Ecorr, $\mathrm{mV}$, and concrete resistivity for Symphonia globulifera linn, Ficus glumosa and acardium occidentale 1 are $29.9 \%$ and $63.6 \%$ , $23.75 \%$ and $66.48 \%$ and $27.45 \%$ and $68.45 \%$ respectively.

\subsection{MATERIALS AND METHODS FOR EXPERINMENT \\ 2.1 Aggregates}

The fine aggregate and coarse aggregate were purchased. Both met the requirements of ${ }^{[15]}$.

\subsubsection{Cement}

Portland limestone cement grade 42.5 is the most and commonly type of cement in Nigerian Market. It was used for all concrete mixes in this investigation. The cement met the requirements of ${ }^{[16]}$

\subsubsection{Water}

The water samples were clean and free from impurities. The fresh water used was gotten from the tap at the Civil Engineering Department Laboratory, Kenule Beeson Polytechnic, Bori, Rivers State. The water met the requirements of ${ }^{[17]}$

\subsubsection{Structural Steel Reinforcement}

The reinforcements are gotten directly from the market in Port Harcourt ${ }^{[18]}$

\subsubsection{Corrosion Inhibitor (Resins / Exudates) Celtis zenkeri}

The study inhibitor is Celtis zenkeri of natural tree resins /exudates substance extracts.

\subsection{Experimental Procedures}

\subsubsection{Experimental method}

\subsubsection{Sample preparation for reinforcement with coated resin/exudates}

The corrosion rates were quantified predicated on current density obtained from the polarization curve and the corrosion rate quantification set-up. Fresh concrete mix batch were fully compacted to remove trapped air, with concrete cover of $15 \mathrm{~mm}$ and projection of $150 \mathrm{~mm}$ for half cell potential measurement and concrete resistivity tests. The polarization curve was obtained as the relationship between corrosion potential and current density. The samples were designed with sets of reinforced concrete slab of $150 \mathrm{~mm}$ thick x $350 \mathrm{~mm}$ width $\mathrm{x} 900 \mathrm{~mm}$ long, uncoated and coated specimens of above thicknesses were embedded into the concrete, spaced at $150 \mathrm{~mm}$ apart. The corrosion cell consisted of a saturated calomel reference electrode (SCE), counter electrode (graphite rod) and the reinforcing steel embedded in concrete specimen acted as the working electrode. Slabs were demoulded after 72 hours and cured for 28 days with room temperature and corrosion acceleration ponding process with Sodium Chloride lasted for 150days with 14 days checked intervals for readings. Mix ratio of 1:2:3 by weight of concrete, water cement ratio of 0.65 , and manual mixing was adopted

\subsection{Accelerated Corrosion Test}

The accelerated corrosion test allows the acceleration of corrosion to reinforcing steel embedded in concrete and can simulate corrosion growth that would occur over decades. In order to test concrete resistivity and durability against corrosion, it was necessary to design 
an experiment that would accelerate the corrosion process and maximize the concrete's resistance against corrosion until failure. An accelerated corrosion test is the impressed current technique which is an effective technique to investigate the corrosion process of steel in concrete and to assess the damage on the concrete cover. A laboratory acceleration process helps to distinguish the roles of individual factors that could affect chloride induced corrosion. Therefore, for design of structural members and durability against corrosion as well as selection of suitable material and appropriate protective systems, it is useful to perform accelerated corrosion tests for obtaining quantitative and qualitative information on corrosion.

\subsection{Corrosion Current Measurements (Half-cell potential measurements)}

Classifications of the severity of rebar corrosion rates are presented in Table 2.1. If the potential

measurements indicate that there is a high probability of active corrosion, concrete resistivity measurement can be subsequently used to estimate the rate of corrosion. However, caution needs to be exercised in using data of this nature, since constant corrosion rates with time are assumed. This was also stated from practical experience (Figg and Marsden, 1985 and Langford and Broomfield ,1987). Half-cell potential measurements are indirect method of assessing potential bar corrosion, but there has been much recent interest in developing a means of performing perturbative electrochemical measurements on the steel itself to obtain a direct evaluation of the corrosion rate (Gowers and Millard, 1999a). Corrosion rates have been related to electrochemical measurements based on data first reported by Stern and Geary (1957).

Table 2.1: Dependence between potential and corrosion probability

\begin{tabular}{|l|l|}
\hline Potential $E_{\text {corr }}$ & Probability of corrosion \\
\hline$E$ corr $<-350 \mathrm{mV}$ & $\begin{array}{l}\text { Greater than } 90 \% \text { probability that reinforcing steel corrosion is } \\
\text { occurring in that area at the time of measurement }\end{array}$ \\
\hline$-350 \mathrm{mV} \leq E \mathrm{c}_{\text {orr }} \leq-200 \mathrm{mV}$ & Corrosion activity of the reinforcing steel in that area is uncertain \\
\hline$E_{\text {corr }}>-200 \mathrm{mV}$ & $\begin{array}{l}90 \% \text { probability that no reinforcing steel corrosion is occurring in } \\
\text { that area at the time of measurement (10\% risk of corrosion }\end{array}$ \\
\hline
\end{tabular}

\subsection{Concrete Resistivity Measurement Test}

Different readings were taken at different locations at the surface of the concrete. After applying water on the surface of the slabs, the concrete resistivity was measured daily at the reference locations, looking for the saturation condition. These locations were chosen at the side of the slabs, since concrete electrical resistivity measurements could be taken when water was on the top surface of the slab. The mean values of the readings were recorded as the final readings of the resistivity in the study. The saturation level of the slabs was monitored through concrete electrical resistivity measurements, which are directly related to the moisture content of concrete. Once one slab would reach the saturated condition, the water could be drained from that slab, while the other slabs remained ponded. Time limitation was the main challenge to perform all the experimental measurements, as the concrete saturation condition changes with time. In the study, the Wenner four probes method was used; it was done by placing the four probes in contact with the concrete directly above the reinforcing steel bar. Henceforth, these measurements will be referred to as the measurements in «dry» conditions. Since each of the slabs had a different w/c, the time needed to saturate 
each of the slabs was not the same. Before applying water on the slabs, the concrete electrical resistivity was measured in the dry condition at the specified locations. The electrical resistivity becomes constant once the concrete has reached saturation.

Table 2.2: Dependence between concrete resistivity and corrosion probability

\begin{tabular}{|l|l|}
\hline Concrete resistivity $\boldsymbol{\rho}, \mathbf{k} \mathbf{\Omega} \mathbf{c m}$ & Probability of corrosion \\
\hline$\rho<5$ & Very high \\
\hline $5<\rho<10$ & High \\
\hline $10<\rho<20$ & Low to moderate \\
\hline$\rho>20$ & Low \\
\hline
\end{tabular}

\subsection{Tensile Strength of Reinforcing Bars}

To ascertain the yield and tensile strength of tension bars, bar specimens of $12 \mathrm{~mm}$ diameter of Control, corroded and coated were tested in tension in a Universal Testing Machine and were subjected to direct tension until failure; the yield, maximum and failure loads being recorded. To ensure consistency, the remaining cut pieces from the standard length of corroded and Control steel bars were subsequently used for mechanical properties of steel

\subsection{EXPERIMENTAL RESULTS AND DISCUSSION}

The results of the half-cell potential measurements in table 3.1 were plotted against concrete resistivity of table 3.2 for easy interpretation. It used as indication of likelihood of significant corrosion $(\rho<5,5<\rho<10,10<\rho<20, \rho>20)$ for Very high, High, Low to moderate and Low, for Probability of corrosion. In the other measuring points, potential Ecorr is high $\left(-350 \mathrm{mV} \leq E_{\text {corr }} \leq-200 \mathrm{mV}\right)$, which indicates a $10 \%$ or uncertain probability of corrosion. Results of the concrete resistivity measurements are shown in Table 3.2. It is evident that potential $E_{\text {corr }}$ if low $(<-350 \mathrm{mV})$ in an area measuring indicates a $95 \%$ probability of corrosion. Concrete resistivity is commonly measured by four-electrode method. Resistivity survey data gives an indication of whether the concrete condition is favorable for the easy movements of ions leading to more corrosion.

\subsection{Control Concrete Slab Members}

Tables 3.1 into 3.1A, are the results of preliminary and average results gotten from control, corroded and exudates/resin coated specimens of $150 \mu \mathrm{m}, 300 \mu \mathrm{m}, 450 \mu \mathrm{m}$ thicknesses and plotted in figures 3.1 and $3.1 \mathrm{~A}$ of concrete resistivity $\rho, \mathrm{k} \Omega \mathrm{cm}$ versus potential $\mathrm{E}_{\mathrm{corr}} \mathrm{mV}$. Average potential Ecorr control specimens results are $-101.81 \mathrm{mV},-101.28 \mathrm{mV},-100.76 \mathrm{mV}$, fused into $-101.283 \mathrm{mV}$, with percentile average value $29.66015 \%$ and percentile difference $70.3398 \%$. Average results of concrete resistivity $\rho, \mathrm{k} \Omega \mathrm{cm}$ from table 3.2 into $3.2 \mathrm{~A}$ and plotted in figures 3.2 and $3.2 \mathrm{~A}$ are $14.4022 \mathrm{k} \Omega \mathrm{cm}, 14.4022 \mathrm{k} \Omega \mathrm{cm}, 14.4022 \mathrm{k} \Omega \mathrm{cm}$, fused into $14.4022 \mathrm{k} \Omega \mathrm{cm}$ with percentile average value $218.2868 \%$ and percentile difference $118.2868 \%$. Average mechanical properties "ultimate strength" of control specimens from table 3.3 into $3.3 \mathrm{~A}$ and plotted in figures 3.3 and $3.3 \mathrm{~A}$ are $547.1783 \mathrm{~N} / \mathrm{mm}^{2}, 545.9783 \mathrm{~N} / \mathrm{mm}^{2}$, $546.3783 \mathrm{~N} / \mathrm{mm}^{2}$, fused into $546.5117 \mathrm{~N} / \mathrm{mm}^{2}$, with percentile average value $91.92872 \%$ and percentile difference --8.07128\%. Average mechanical properties "weight loss of steel" of control from table 3.4 into 3.4A and plotted in figures 3.4 and 3.4A are 7.008667 grams, 7.008667grams, 6.962grams, fused into 6.993111grams with percentile average value $54.87327 \%$ and percentile difference $-45.1267 \%$. Average mechanical properties "crosssection area reduction" of control from table 3.5 into 3.5A and plotted in figures 3.5 and $3.5 \mathrm{~A}$ are $12 \mathrm{~mm}, 12 \mathrm{~mm}, 12 \mathrm{~mm}$ and fused into $12 \mathrm{~mm}$ with percentile average value 
$116.0417 \%$ and percentile difference $16.04169 \%$. Control specimens result showed no corrosion potential.

\subsection{Corroded Concrete Slab Members}

Unsystematic 27 slab samples of results from tables 3.1 into 3.1A illustrated the average values of control, corroded and exudates/resin coated specimens of $150 \mu \mathrm{m}, 300 \mu \mathrm{m}, 450 \mu \mathrm{m}$ and shown in figures 3.1 and $3.1 \mathrm{~A}$ of potential $\mathrm{E}_{\mathrm{corr}}{ }_{\mathrm{mV}}$. Average potential $\mathrm{E}_{\text {corr }}$ corroded values are $-272.613 \mathrm{mV}-351.913 \mathrm{mV},-399.913 \mathrm{mV}$ fused into $-341.479 \mathrm{mV}$, with percentile average value $337.1527 \%$ and percentile difference $237.1527 \%$ against $-70.3398 \%$ and $67.7193 \%$ of control and coated specimens. Potential $\mathrm{E}_{\text {corr }}$ results showed that the values of non-coated specimens are high with the range of $\left(-350 \mathrm{mV} \leq E_{\text {corr }} \leq-200 \mathrm{mV}\right)$, which indicates a $10 \%$ or uncertain probability of corrosion. Average results of concrete resistivity $\rho, \mathrm{k} \Omega \mathrm{cm}$ from table 3.2 into $3.2 \mathrm{~A}$ and plotted in figures 3.2 and $3.2 \mathrm{~A}$ are $6.597833 \mathrm{k} \Omega \mathrm{cm}$, $6.597833 \mathrm{k} \Omega \mathrm{cm}, 6.597833 \mathrm{k} \Omega \mathrm{cm}$, fused into $6.597833 \mathrm{k} \Omega \mathrm{cm}$ with percentile average value $45.81129 \%$ and percentile difference $-54.1887 \%$ against $118.2868 \%$ and $117.675 \%$ of control and coated specimens. Range of values of non-coated specimens showed indication of likelihood of significant corrosion $(\rho<5,5<\rho<10,10<\rho<20, \rho>20)$ for very high, high, low to moderate and low, for probability of corrosion. Average mechanical properties "ultimate strength" of corroded specimens from table 3.3 into 3.3A and plotted in figures 3.3 and $3.3 \mathrm{~A}$ are $595.3617 \mathrm{~N} / \mathrm{mm}^{2}, 593.0617 \mathrm{~N} / \mathrm{mm}^{2}, 595.0617 \mathrm{~N} / \mathrm{mm}^{2}$, fused into $594.495 \mathrm{~N} / \mathrm{mm}^{2}$, with percentile average value $108.7799 \%$ and percentile difference $8.779928 \%$ against $8.07128 \%$ and $-7.93467 \%$ of control and coated specimens. Results showed high ultimate yielding of corroded specimens to control and coated specimens due to the effect of corrosion on the mechanical properties of the steel reinforcement. Average mechanical properties "weight loss of steel" of corroded specimens from table 3.4 into 3.4A and plotted in figures 3.4 and $3.4 \mathrm{~A}$ are $12.72933 \mathrm{grams}, 12.72933 \mathrm{grams}, 12.77367 \mathrm{grams}$, fused into $12.74411 \mathrm{grams}$ with percentile average value $182.2381 \%$ and percentile difference $82.23808 \%$ against $45.1267 \%$ and $-45.4432 \%$ of control and coated specimens. Results of weight loss of Steel showed higher percentile values against control and coated specimens due to the effect of corrosion on the mechanical properties of steel. Average mechanical properties "crosssection area reduction" of control from table 3.5 into 3.5A and plotted in figures 3.5 and $3.5 \mathrm{~A}$ are $10.26333 \mathrm{~mm}, 10.26333 \mathrm{~mm}, 10.49667 \mathrm{~mm}$ and fused into $10.34111 \mathrm{~mm}$ with percentile average value $86.17593 \%$ and percentile difference $-13.8241 \%$ against $16.04169 \%$ and $16.04169 \%$. Cross- section area reduction results showed higher percentile reduction values due to effect of corrosion on the mechanical properties of steel.

\subsection{Celtis zenkeri exudates Steel Bar Coated Concrete Slab Members}

Results from tables 3.1 into 3.1A, averaged values of control, corroded and exudates/resin coated specimens of $150 \mu \mathrm{m}, 300 \mu \mathrm{m}, 450 \mu \mathrm{m}$ as presented in figures 3.1 and $3.1 \mathrm{~A}$ of concrete resistivity $\rho, \mathrm{k} \Omega \mathrm{cm}$ versus potential $\mathrm{E}_{\text {corr, }}{ }^{\mathrm{mV}}$ relationship which showed average potential Ecorr control values of $-110.281 \mathrm{mV},-110.111 \mathrm{mV},-110.304 \mathrm{mV}$ derived into $-110.232 \mathrm{mV}$, with percentile average value $32.28066 \%$ and percentile difference $-67.7193 \%$ over $237.1527 \%$ corroded specimen. Concrete resistivity $\rho, \mathrm{k} \Omega \mathrm{c}$ average results from table 3.2 into $3.2 \mathrm{~A}$ and plotted in figures 3.2 and $3.2 \mathrm{~A}$ are $14.36183 \mathrm{k} \Omega \mathrm{cm}, 14.36183 \mathrm{k} \Omega \mathrm{cm}$, $14.36183 \mathrm{k} \Omega \mathrm{cm}$, fused into $14.36183 \mathrm{k} \Omega \mathrm{cm}$ with percentile average value $217.675 \%$ and percentile difference $117.675 \%$ over $-54.1887 \%$ corroded specimen. Average mechanical properties "ultimate strength" of control specimens from table 3.3 into $3.3 \mathrm{~A}$ and plotted in figures 3.3 and $3.3 \mathrm{~A}$ are $546.096 \mathrm{~N} / \mathrm{mm}^{2}, 547.396 \mathrm{~N} / \mathrm{mm}^{2}, 548.4793 \mathrm{~N} / \mathrm{mm}^{2}$, derived into $547.3238 \mathrm{~N} / \mathrm{mm}^{2}$, with percentile average value $92.06533 \%$ and percentile difference $7.93467 \%$ over $8.779928 \%$ corroded specimen. Average mechanical properties "weight loss 
of steel" of control from table 3.4 into 3.4A and plotted in figures 3.4 and 3.4A are 6.945grams, 6.945grams, 6.968333grams, fused into 6.952778grams with percentile average value $54.55679 \%$ and percentile difference $-45.4432 \%$ over $82.23808 \%$ corroded. Average mechanical properties "cross- section area reduction" of control from table 3.5 into 3.5A and plotted in figures 3.5 and $3.5 \mathrm{~A}$ are $12 \mathrm{~mm}, 12 \mathrm{~mm}, 12 \mathrm{~mm}$ and fused into $12 \mathrm{~mm}$ with percentile average value $116.0417 \%$ and percentile difference $16.04169 \%$ over $-13.8241 \%$ corroded specimen. Control specimens result showed no corrosion potential.

Table 3.1 : Potential Ecorr, after 28 days curing and 150 days Accelerated Periods

\begin{tabular}{|c|c|c|c|c|c|c|c|c|c|}
\hline & \multicolumn{9}{|c|}{ Potential $\mathbf{E}_{\text {corr,mV }}$} \\
\hline & \multicolumn{9}{|c|}{ Time Intervals after 28 days curing } \\
\hline Samples & AF1 & AF2 & AF3 & AF4 & AF5 & AF6 & AF7 & AF8 & AF9 \\
\hline \multirow[t]{2}{*}{ Durations } & (7days) & (21days) & ( & ( 58 days) & (88days) & (118days) & (148days) & (163days) & (178days) \\
\hline & \multicolumn{9}{|c|}{ Control Concrete slab Specimens } \\
\hline CSLA1 & -102.88 & -102.25 & -100.3 & -101.28 & -101.72 & -100.84 & -100.37 & -101.44 & -100.47 \\
\hline \multirow[t]{4}{*}{ CSLB1 } & \multicolumn{9}{|c|}{ Corroded Concrete Slab Specimens } \\
\hline & -243.846 & -270.046 & -303.946 & -343.046 & -352.846 & -359.846 & -393.746 & -400.946 & -405.046 \\
\hline & \multicolumn{9}{|c|}{ Celtis zenkeri exudates ( steel bar coated specimen) } \\
\hline & \multicolumn{3}{|c|}{$(150 \mu \mathrm{m})$ coated } & \multicolumn{3}{|c|}{$(300 \mu \mathrm{m})$ coated } & \multicolumn{3}{|c|}{$(450 \mu m)$ coated } \\
\hline CSLC1 & -109.324 & -106.994 & -114.524 & -109.694 & -106.634 & -114.004 & -108.924 & -112.694 & -109.294 \\
\hline
\end{tabular}

Table 3.1A : Average Potential Ecorr, after 28 days curing and 150 days Accelerated Periods

\begin{tabular}{|c|c|c|c|c|c|c|c|}
\hline S/no & Samples & $\begin{array}{c}\text { Average } \\
\text { A }\{\mathrm{F}(7,8,9\end{array}$ & $\{\mathrm{F}(1,2,3)\}$, & ,5,6)\}, & $\begin{array}{l}\text { Summary } \\
\text { Average } \\
\mathrm{A}\{\mathrm{F}(1,2,3)\}, \\
(4,5,6)\}, \\
\mathrm{A}\{\mathrm{F}(7,8,9)\} \\
\end{array}$ & $\begin{array}{l}\text { Percentile Average } \\
\text { Values Average } \\
\mathrm{A}\{\mathrm{F}(1,2,3)\},(4,5,6)\} \text {, } \\
\mathrm{A}\{\mathrm{F}(7,8,9)\}\end{array}$ & $\begin{array}{l}\text { Percentile Difference } \\
\text { Average } \\
\text { A }\{\mathrm{F}(1,2,3)\},(4,5,6)\} \text {, } \\
\mathrm{A}\{\mathrm{F}(7,8,9)\}\end{array}$ \\
\hline & \multicolumn{7}{|c|}{ Potential $\mathbf{E}_{\text {corr,mv }}$} \\
\hline CSLA1 & $\begin{array}{l}\text { Control } \\
\text { Specimens }\end{array}$ & -101.81 & -101.28 & -100.76 & -101.283 & 29.66015 & -70.3398 \\
\hline CSLB1 & $\begin{array}{l}\text { Corroded } \\
\text { Specimens } \\
\end{array}$ & -272.613 & -351.913 & -399.913 & -341.479 & 337.1527 & 237.1527 \\
\hline CSLC1 & $\begin{array}{l}\text { Coated } \\
\text { Specimens }\end{array}$ & -110.281 & -110.111 & -110.304 & -110.232 & 32.28066 & -67.7193 \\
\hline
\end{tabular}

Table 3.2 : Results of Concrete Resistivity $\rho, \mathrm{k} \Omega \mathrm{cm}$ Time Intervals after 28 days curing and 150 days Accelerated Periods

\begin{tabular}{|c|c|c|c|c|c|c|c|c|c|}
\hline & \multicolumn{9}{|c|}{ Concrete Resistivity $\rho, \mathrm{k} \Omega \mathrm{cm}$} \\
\hline & \multicolumn{9}{|c|}{ Time Intervals after 28 days curing } \\
\hline Samples & AF1 & $\mathrm{AF} 2$ & AF3 & $\mathrm{AF} 4$ & AF5 & AF6 & AF7 & AF8 & AF9 \\
\hline \multirow{2}{*}{ Durations } & (7days) & (21days) & (28days) & (58days) & (88days) & (118days) & (148days) & (163days) & (178days) \\
\hline & \multicolumn{9}{|c|}{ Control Concrete slab Specimens } \\
\hline CSLA2 & 14.3222 & 14.4922 & 14.3922 & 14.6222 & 14.4522 & 13.4022 & 14.4222 & 14.4222 & 14.4522 \\
\hline CSLB2 & \multicolumn{9}{|c|}{ Corroded Concrete Slab Specimens } \\
\hline & 5.7735 & 6.095 & 7.925 & 6.235 & 7.405 & 7.565 & 7.305 & 7.735 & 7.775 \\
\hline \multirow[t]{3}{*}{ CSLC2 } & \multicolumn{9}{|c|}{ Celtis zenkeri exudates ( steel bar coated specimen) } \\
\hline & \multicolumn{3}{|c|}{$(150 \mu \mathrm{m})$ coated } & \multicolumn{3}{|c|}{$(300 \mu \mathrm{m})$ coated } & \multicolumn{3}{|c|}{$(450 \mu \mathrm{m})$ coated } \\
\hline & 14.1685 & 14.3185 & 14.5985 & 14.7285 & 14.4185 & 14.7085 & 14.6585 & 14.8085 & 14.8385 \\
\hline
\end{tabular}


Table 3.2B : Average Results of Concrete Resistivity $\rho, \mathrm{k} \Omega \mathrm{cm}$ Time Intervals after 28 days curing and 150 days Accelerated Periods

\begin{tabular}{|c|c|c|c|c|c|c|c|}
\hline S/no & Samples & $\begin{array}{l}\text { Average A }\{ \\
\mathrm{A}\{\mathrm{F}(7,8,9)\}\end{array}$ & $1,2,3)\},(4,5$ & & $\begin{array}{l}\text { Summary } \\
\text { Average } \\
\text { A }\{\mathrm{F}(1,2,3)\}, \\
(4,5,6)\}, \\
\text { A }\{\mathrm{F}(7,8,9)\}\end{array}$ & $\begin{array}{l}\text { Percentile } \\
\text { Average Values } \\
\text { Average } \\
\mathrm{A}\{\mathrm{F}(1,2,3)\}, \\
(4,5,6)\}, \\
\mathrm{A}\{\mathrm{F}(7,8,9)\}\end{array}$ & $\begin{array}{l}\text { Percentile } \\
\text { Difference } \\
\text { Average } \\
\mathrm{A}\{\mathrm{F}(1,2,3)\}, \\
(4,5,6)\}, \\
\mathrm{A}\{\mathrm{F}(7,8,9)\}\end{array}$ \\
\hline & \multicolumn{7}{|c|}{ Concrete Resistivity $\rho, \mathrm{k} \Omega \mathrm{cm}$} \\
\hline CSLA2 & $\begin{array}{c}\text { Control } \\
\text { Specimens }\end{array}$ & 14.4022 & 14.4022 & 14.4022 & 14.4022 & 218.2868 & 118.2868 \\
\hline CSLB2 & $\begin{array}{c}\text { Corroded } \\
\text { Specimens }\end{array}$ & 6.597833 & 6.597833 & 6.597833 & 6.597833 & 45.81129 & -54.1887 \\
\hline CSLC2 & $\begin{array}{c}\text { Coated } \\
\text { Specimens }\end{array}$ & 14.36183 & 14.36183 & 14.36183 & 14.36183 & 217.675 & 117.675 \\
\hline
\end{tabular}

Table 3.3 : Mechanical properties of Control, Corroded and Steel Coated Concrete Slab

\begin{tabular}{|c|c|c|c|c|c|c|c|c|c|}
\hline & \multicolumn{9}{|c|}{ Time Intervals after 28 days curing } \\
\hline Samples & AF1 & $\mathrm{AF} 2$ & AF3 & AF4 & AF5 & AF6 & AF7 & AF8 & AF9 \\
\hline \multirow[t]{2}{*}{ Durations } & (7days) & (21days) & (28days) & (58days) & (88days) & (118days) & (148days) & (163days) & (178days) \\
\hline & \multicolumn{9}{|c|}{ Yield Stress (N/mm2) for Control, Corroded and Coated Specimens } \\
\hline \multirow[t]{3}{*}{ CSLA3 } & 410 & 410 & 410 & 410 & 410 & 410 & 410 & 410 & 410 \\
\hline & \multicolumn{9}{|c|}{ Ultimate strength $(\mathrm{N} / \mathrm{mm} 2)$} \\
\hline & \multicolumn{9}{|c|}{ Control Concrete slab Specimens } \\
\hline CSLB3 & 547.645 & 548.545 & 545.345 & 545.545 & 549.745 & 545.145 & 548.145 & 545.645 & 545.345 \\
\hline \multirow[t]{2}{*}{ CSLC3 } & \multicolumn{9}{|c|}{ Corroded Concrete Slab Specimens } \\
\hline & 594.295 & 595.395 & 596.395 & 592.395 & 596.395 & 592.395 & 594.995 & 592.195 & 597.995 \\
\hline \multirow[t]{3}{*}{ CSLD3 } & \multicolumn{9}{|c|}{ Celtis zenkeri exudates ( steel bar coated specimen) } \\
\hline & \multicolumn{3}{|c|}{$(150 \mu \mathrm{m})$ coated } & \multicolumn{3}{|c|}{$(300 \mu \mathrm{m})$ coated } & \multicolumn{3}{|c|}{$(450 \mu \mathrm{m})$ coated } \\
\hline & 546.996 & 546.296 & 544.996 & 547.396 & 547.396 & 547.396 & 550.096 & 547.046 & 548.296 \\
\hline
\end{tabular}

Table 3.3A : Average Mechanical properties of Control, Corroded and Steel Coated Concrete Slab

\begin{tabular}{|c|c|c|c|c|c|c|c|}
\hline S/no & Samples & \multicolumn{2}{|c|}{$\begin{array}{l}\text { Average A }\{\mathrm{F}(1,2,3)\},(4,5,6)\}, \\
\mathrm{A}\{\mathrm{F}(7,8,9)\}\end{array}$} & $\begin{array}{l}\text { Summary Average } \\
\mathrm{A}\{\mathrm{F}(1,2,3)\}, \\
(4,5,6)\}, \\
\mathrm{A}\{\mathrm{F}(7,8,9)\}\end{array}$ & $\begin{array}{l}\text { Percentile Average } \\
\text { Values Average } \\
\mathrm{A}\{\mathrm{F}(1,2,3)\},(4,5,6)\}, \\
\mathrm{A}\{\mathrm{F}(7,8,9)\}\end{array}$ & $\begin{array}{l}\text { Percentile } \\
\text { Difference } \\
\text { Average } \\
\text { Af }\{1,2,3)\},( \\
4,5,6)\}, \\
\text { A }\{\mathrm{F}(7,8,9)\}\end{array}$ \\
\hline CSLB3 & $\begin{array}{c}\text { Control } \\
\text { Specimens }\end{array}$ & 547.1783 & 545.9783 & 546.3783 & 546.5117 & 91.92872 & -8.07128 \\
\hline CSLC3 & $\begin{array}{c}\text { Corroded } \\
\text { Specimens }\end{array}$ & 595.3617 & 593.0617 & 595.0617 & 594.495 & 108.7799 & 8.779928 \\
\hline CSLD3 & $\begin{array}{c}\text { Coated } \\
\text { Specimens }\end{array}$ & 546.096 & 547.396 & 548.4793 & 547.3238 & 92.06533 & -7.93467 \\
\hline
\end{tabular}


Table 3.4 : Mechanical properties of Control, Corroded and Steel Coated Concrete Slab

\begin{tabular}{|c|c|c|c|c|c|c|c|c|c|}
\hline & \multicolumn{9}{|c|}{ Weight Loss of Steel (in grams) } \\
\hline & \multicolumn{9}{|c|}{ Control Concrete slab Specimens } \\
\hline CSLA4 & 6.942 & 7.062 & 7.022 & 6.942 & 6.952 & 7.142 & 6.972 & 6.872 & 7.042 \\
\hline CSLB4 & \multicolumn{9}{|c|}{ Corroded Concrete Slab Specimens } \\
\hline & 12.603 & 12.771 & 12.814 & 12.851 & 12.857 & 12.859 & 12.81 & 12.86 & 12.651 \\
\hline CSLC4 & \multicolumn{9}{|c|}{ Celtis zenkeri exudates ( steel bar coated specimen) } \\
\hline & \multicolumn{3}{|c|}{$(150 \mu m)$ coated } & \multicolumn{3}{|c|}{$(300 \mu \mathrm{m})$ coated } & \multicolumn{3}{|c|}{$(450 \mu \mathrm{m})$ coated } \\
\hline & 6.935 & 6.945 & 6.955 & 6.945 & 6.985 & 6.945 & 6.985 & 6.945 & 6.975 \\
\hline
\end{tabular}

Table 3.4A : Average Mechanical properties of Control, Corroded and Steel Coated Concrete Slab

\begin{tabular}{|l|l|c|c|c|c|c|c|}
\hline S/no & Samples & \multicolumn{2}{|c|}{$\begin{array}{c}\text { Average A }\{\mathrm{F}(1,2,3)\},(4,5,6)\}, \\
\mathrm{A}\{\mathrm{F}(7,8,9)\}\end{array}$} & $\begin{array}{l}\text { Summary } \\
\text { Average } \\
\mathrm{A}\{\mathrm{F}(1,2,3)\}, \\
(4,5,6)\}, \\
\mathrm{A}\{\mathrm{F}(7,8,9)\}\end{array}$ & $\begin{array}{l}\text { Percentile Average } \\
\text { Values Average } \\
\mathrm{A}\{\mathrm{F}(1,2,3)\},(4,5,6)\}, \\
\mathrm{A}\{\mathrm{F}(7,8,9)\}\end{array}$ & $\begin{array}{l}\text { Percentile Difference } \\
\text { Average } \\
\mathrm{A}\{\mathrm{F}(1,2,3)\},(4,5,6)\}, \\
\mathrm{A}\{\mathrm{F}(7,8,9)\}\end{array}$ \\
\hline & \multicolumn{7}{|c|}{ Weight Loss of Steel (in grams) } \\
\hline CSLA4 & $\begin{array}{c}\text { Control } \\
\text { Specimens }\end{array}$ & 7.008667 & 7.008667 & 6.962 & 6.993111 & 54.87327 & -45.1267 \\
\hline CSLB4 & $\begin{array}{c}\text { Corroded } \\
\text { Specimens }\end{array}$ & 12.72933 & 12.72933 & 12.77367 & 12.74411 & 182.2381 & 82.23808 \\
\hline CSLC4 & $\begin{array}{c}\text { Coated } \\
\text { Specimens }\end{array}$ & 6.945 & 6.945 & 6.968333 & 6.952778 & 54.55679 & -45.4432 \\
\hline
\end{tabular}

Table 3.5 : Mechanical properties of Control, Corroded and Steel Coated Concrete Slab

\begin{tabular}{|c|c|c|c|c|c|c|c|c|c|}
\hline & \multicolumn{9}{|c|}{ Cross- section Area Reduction ( Diameter, mm) } \\
\hline & \multicolumn{9}{|c|}{ Control Concrete slab Specimens } \\
\hline CSLA5 & 12 & 12 & 12 & 12 & 12 & 12 & 12 & 12 & 12 \\
\hline CSLB5 & \multicolumn{9}{|c|}{ Corroded Concrete Slab Specimens } \\
\hline & 10.26 & 10.26 & 10.27 & 10.34 & 10.37 & 10.44 & 10.48 & 10.49 & 10.52 \\
\hline & \multicolumn{9}{|c|}{ Celtis zenkeri exudates ( steel bar coated specimen) } \\
\hline & \multicolumn{3}{|c|}{$(150 \mu \mathrm{m})$ coated } & \multicolumn{3}{|c|}{$(300 \mu \mathrm{m})$ coated } & \multicolumn{3}{|c|}{$(450 \mu \mathrm{m})$ coated } \\
\hline CSLC5 & 12 & 12 & 12 & 12 & 12 & 12 & 12 & 12 & 12 \\
\hline
\end{tabular}

Table 35 : Mechanical properties of Control, Corroded and Steel Coated Concrete Slab

\begin{tabular}{|c|c|c|c|c|c|c|c|}
\hline S/no & Samples & $\begin{array}{c}\text { Average } \\
\text { A }\{\mathrm{F}(7,8,9\end{array}$ & $\{\mathrm{F}(1,2,3)\}$ & $4,5,6)\}$ & $\begin{array}{l}\text { Summary } \\
\text { Average } \\
\text { A }\{\mathrm{F}(1,2,3)\}, \\
(4,5,6)\}, \\
\mathrm{A}\{\mathrm{F}(7,8,9)\}\end{array}$ & $\begin{array}{l}\text { Percentile Average } \\
\text { Values Average } \\
\mathrm{A}\{\mathrm{F}(1,2,3)\},(4,5,6)\}, \\
\mathrm{A}\{\mathrm{F}(7,8,9)\}\end{array}$ & $\begin{array}{l}\text { Percentile Difference } \\
\text { Average } \\
\mathrm{A}\{\mathrm{F}(1,2,3)\},(4,5,6)\}, \\
\mathrm{A}\{\mathrm{F}(7,8,9)\}\end{array}$ \\
\hline & \multicolumn{7}{|c|}{ Cross- section Area Reduction ( Diameter, mm) } \\
\hline CSLA5 & $\begin{array}{c}\text { Control } \\
\text { Specimens }\end{array}$ & 12 & 12 & 12 & 12 & 116.0417 & 16.04169 \\
\hline CSLB5 & $\begin{array}{c}\text { Corroded } \\
\text { Specimens }\end{array}$ & 10.26333 & 10.26333 & 10.49667 & 10.34111 & 86.17593 & -13.8241 \\
\hline CSLC5 & $\begin{array}{c}\text { Coated } \\
\text { Specimens } \\
\end{array}$ & 12 & 12 & 12 & 12 & 116.0417 & 16.04169 \\
\hline
\end{tabular}




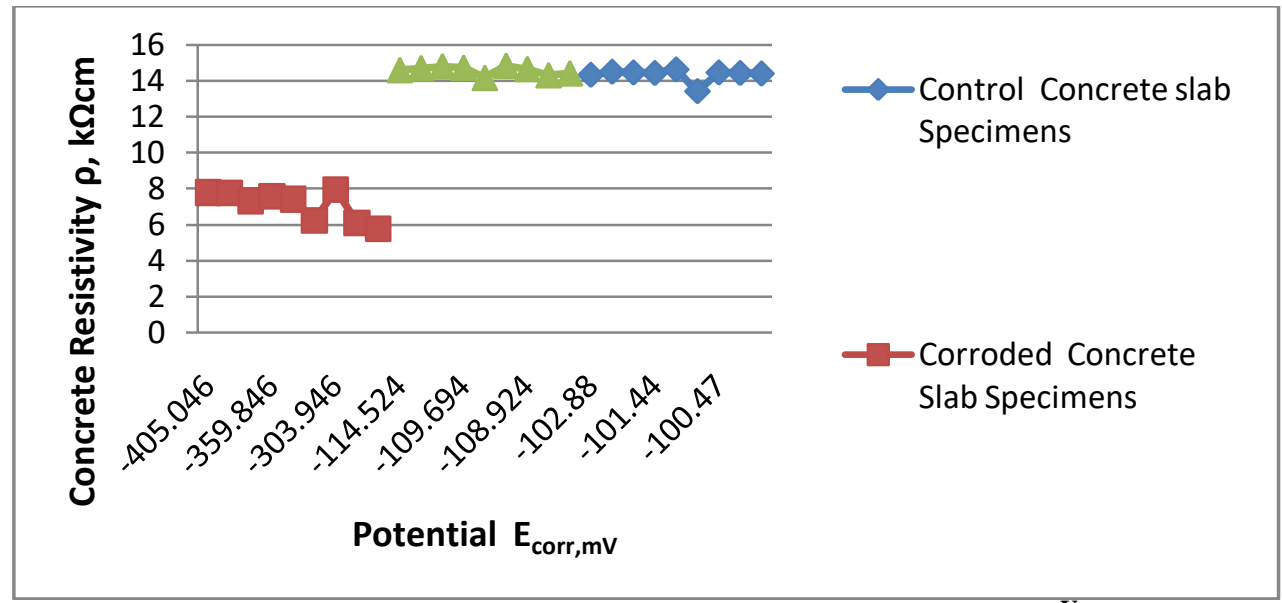

Figure 3.1: Concrete Resistivity $\rho, \mathrm{k} \Omega \mathrm{cm}$ versus Potential $\mathrm{E}_{\mathrm{corr}}{ }^{\mathrm{mv}}{ }^{\mathrm{v}}$ Relationship

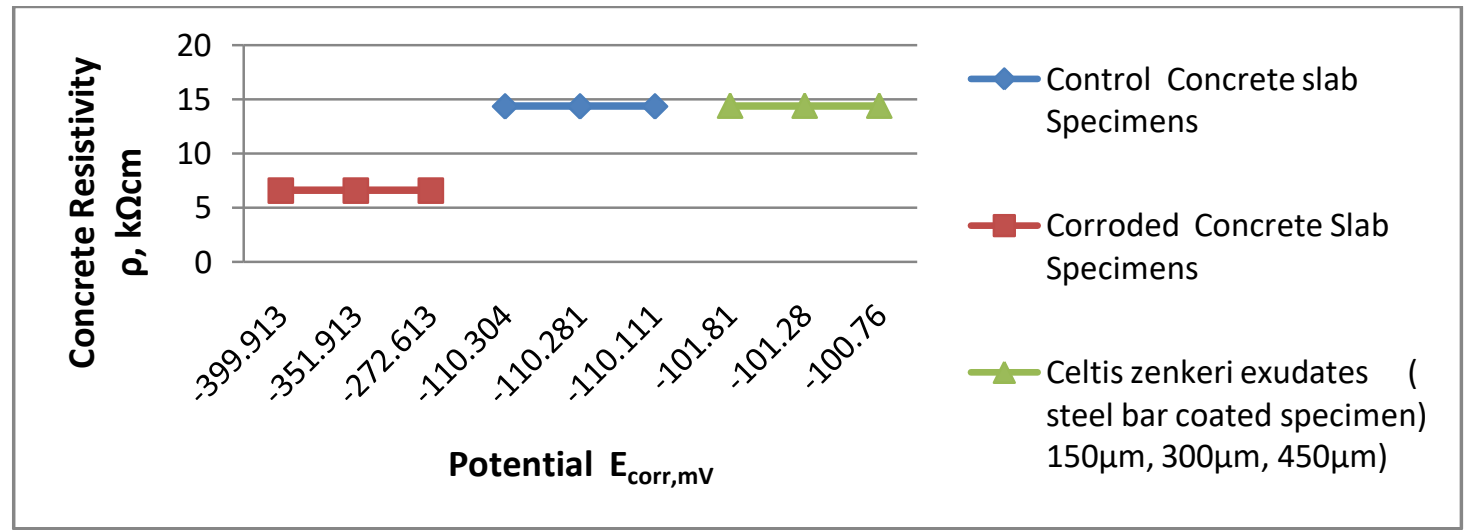

Figure 3.1A: Average Concrete Resistivity versus Potential Relationship

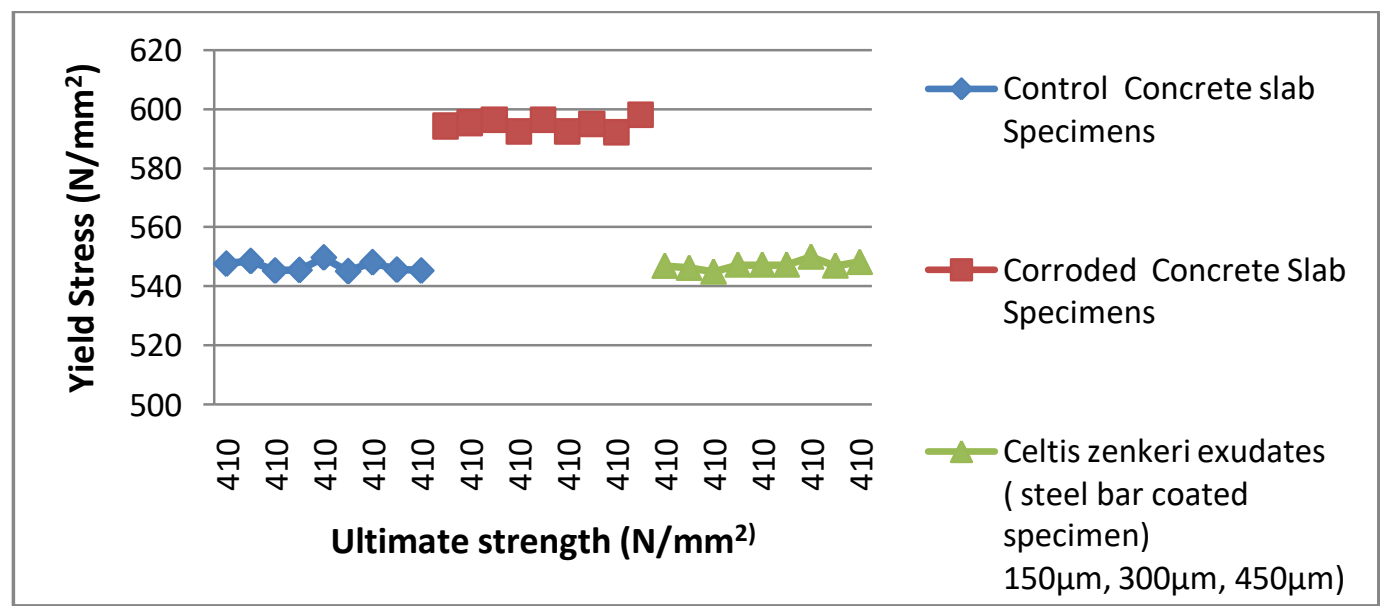

Figure 3.2: Yield Stress versus Ultimate strength 




Figure 3.2A: Average Yield Stress versus Ultimate strength.

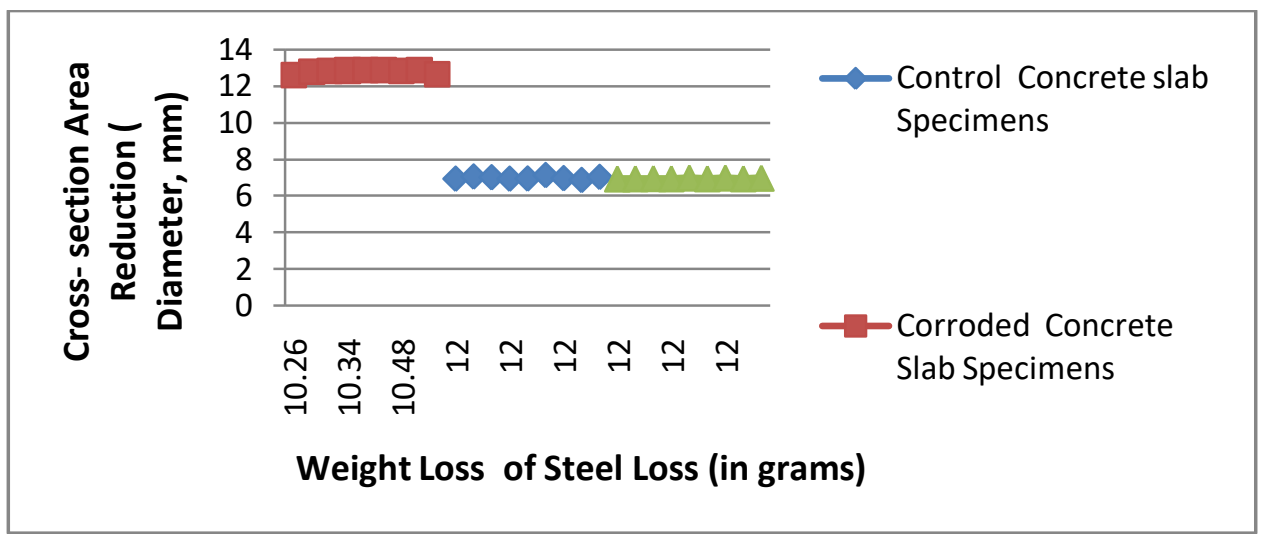

Figure 3.3: Weight Loss of Steel versus Cross- section Area Reduction

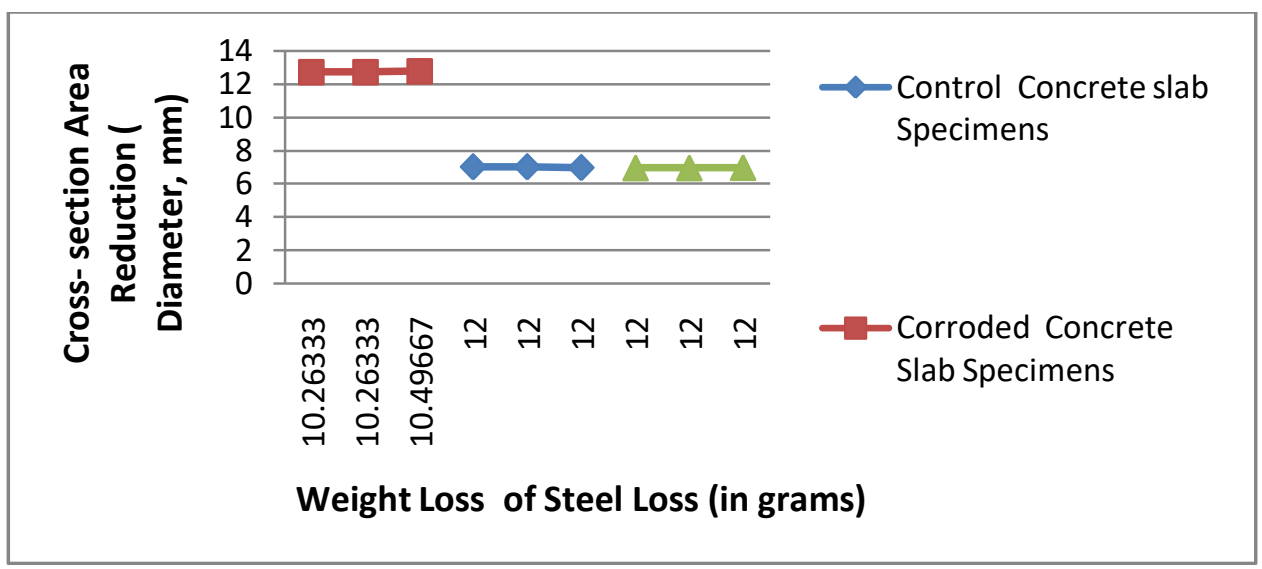

\section{Figure 3.3A: Average Weight Loss of Steel versus Cross- section Area Reduction}

\subsection{CONCLUSION}

Experimental results showed the following conclusions:

i. Results justified the effect of corrosion on the strength capacity of corroded and coated members 
ii. Cross- section area reduction results showed higher percentile reduction values due to effect of corrosion on the mechanical properties of steel

iii. Results of Weight Loss of Steel showed higher percentile values against control and coated specimens due to the effect of corrosion on the mechanical properties of steel

iv. Results showed high ultimate yielding of corroded specimens to control and coated specimens due to the effect of corrosion on the mechanical properties of the steel reinforcement

v. Cross- section area reduction results showed higher percentile reduction values due to effect of corrosion on the mechanical properties of steel

vi. Results of weight loss of Steel showed higher percentile values against control and coated specimens due to the effect of corrosion on the mechanical properties of steel

vii. Results showed high ultimate yielding of corroded specimens to control and coated specimens due to the effect of corrosion on the mechanical properties of the steel reinforcement.

\section{REFERENCES}

1. Mehta, P.K. and Gerwick, B.C. (1982) Cracking-Corrosion Interaction in Concrete Exposed to Marine Environment, Concrete International, 4:45-51.

2. Bentur, A. Diamond, S. and Berke, N. S. (1997). Steel Corrosion in Concrete. E and FN Spon, An imprint of Chapman and Hall, UK.

3. Mammoliti, L. Hansson, C.M. and Hope, B. B. (1999). Corrosion Inhibitors in Concrete, Part II: Effect on Chloride Threshold Values for Corrosion of Steel in Synthetic Pore Solutions.Concrete and Concrete Research,1583-1589.

4. Ormellese, M. Berra, M. Bolzoni, F. and Pastore, T. (2006). Corrosion Inhibitors for Chlorides Induced Corrosion in Reinforced Concrete Structures. Cement and Concrete Research, 36:536-547.

5. Soylev, T. A. and Richardson, M. G. (2008). Corrosion inhibitors for Steel in Concrete: State of the Art Report. Construction and Building Materials, 22: 609-622.

6. González, J.A. Andrade, C. Alonso, C. and Feliu, S. (1995). Comparison of Rates of General Corrosion and Maximum Pitting Penetration on Concrete Embedded Steel Reinforcement. Cement and Concrete Research, 25:257-264.

7. Song, G. (2000). Theoretical Analysis of the Measurement of Polarization Resistance in Reinforced Concrete. Cement and Concrete Composites, 22: 407-415.

8. Charles, K. Bright, A. Irimiagha, P, G. (2018). Investigation on Mechanism of Steel Bar Corrosion of Reinforced Concrete Structures in Aqueous Solution Using Wenner Technique.International Journal of Scientific \& Engineering Research, (9)4: 1731 -1748.

9. Charles, K., Nwinuka, B. and Philip, K. F. O. (2018). Investigation of Corrosion Probability Assessment and Concrete Resistivity of Steel Inhibited Reinforcement of Reinforced Concrete Structures on Severe Condition.International Journal of Scientific \& Engineering Research, (9)4: 1714-1730.

10. Charles, K., Irimiagha, P, G. and Bright, A.. (2018). Investigation of Corrosion Potential Probability and Concrete Resistivity of Inhibited Reinforcement Chloride threshold in Corrosive Environment. International Journal of Scientific \& Engineering Research, (9)4: $1696-1713$.

11. Charles, K., Taneh, A. N. and Watson, O. (2018). Electrochemical Potential Investigation of Inhibited Reinforcement Properties Embedded in Concrete in Accelerated Corrosive Medium. International Journal of Scientific \& Engineering Research, (9)4:1608 -1625.

12. Charles, K., Philip, K. F. O. and Taneh, A. N. (2018). Corrosion Potential Assessment of Eco-friendly Inhibitors Layered Reinforcement Embedded in Concrete Structures in 
Severe Medium. International Journal of Scientific \& Engineering Research, (9)4:1590_ 1607.

13. Charles, K., Philip, K. F. O. and Watson, O. (2018). Comparative Half Cell Potential and Concrete Resistivity Corrosion Probability Assessment of Embedded Coated Steel Reinforcement in Concrete Accelerated Environment. International Journal of Scientific \& Engineering Research, (9)4:141-159.

14. Charles, K. Gbinu, S. K. Bright, A. (2018). Comparative Corrosion Probability Variance of Non-Inhibited and Inhibited Reinforcement in Concrete and Exposed to Accelerated Medium Using Wenner Method. International Journal of Scientific \& Engineering Research,(9)4: 160-179.

15. BS 882; 1992. - Specification for aggregates from natural sources for concrete, British Standards Institute. London, United Kingdom.

16. BS EN 196-6; 2010. - Methods of Testing Cement. Determination of fineness, British Standards Institute. London, United Kingdom.

17. BS 12390-5; 2005 - Testing Hardened Concrete: Flexural Strength Test of Specimens,British Standards Institute. London, United Kingdom.

18. BS 12390-5; 2005 - Testing Hardened Concrete: Flexural Strength Test of Specimens,British Standards Institute. London, United Kingdom. 